\title{
THE RELATIONSHIP BETWEEN FITNESS-RELATED QUALITY, SATISFACTION AND INTENTION ${ }^{1}$
}

\section{FITTNES'A İLISSKIN HIZZMET KALITTESI TATMIN VE NIYYET ARASINDAKİ İLIŞKI}

\author{
Metin ARGAN ${ }^{1}$, Mehpare TOKAY ARGAN ${ }^{2}$, Huseyin KÖSE ${ }^{1}$, Azize SONER \\ ${ }^{1}$ Anadolu University Faculty of Sport Sciences Eskişehir / Turkey \\ ${ }^{2}$ Bilecik Seyh Edebali University Bozüyük Vocational School Bilecik / Turkey
}

Öz: Hizmet kalitesi, tatmin, niyet ve sadakate olan pozitif etkisinden dolayı dünyada önemli derecede ilgi duyulan bir konu haline gelmiştir. Bu çalışma da fitness merkezlerine ilişkin hizmet kalitesi faktörlerinin ve bu faktörlerin tatmin ve niyete olan etkilerini ortaya koymayı amaçlamaktadır. Araştırma kantitatif araştırma yöntemi olan anket çalışması kullanılarak özel spor tesislerinde 233 fitness katılımcisina yönelik olarak gerçekleştirilmiştir. Elde edilen verilere, geçerlilik, güvenilirlik testleri, doğrulayıcı faktör analizi (DFA) ve yapısal eşitlik modellemesi (YEM) uygulanmıştır. Faktör analizi sonuçlarında altı geçerli boyut (tesis, personel, güvenilirlik, empati, duyarlılık, ulaşım ve bakım) ortaya çıkmış olup, bu boyutların bağımlı değişken olan tatmin ve niyetle anlamlı ilişkisi olduğu ifade edilmiştir.

Anahtar Kelimeler: Fitness, Fitness Hizmetleri, Kalite, Fitness Kalitesi, Fitness Hizmet Kalitesi
Abstract: Service quality has received an increasing interest worldwide due to its positive impact on satisfaction, intention and loyalty. The purpose of the study is to reveal the dimensions of service quality related to fitness centers and to analyze the effects of fitness service quality on satisfaction and intention. The study involved a quantitative research methodology employing a questionnaire and convenience sampling with a total sample of 233 members of a private fitness center within the region of middle of the Turkey. The data were subjected to reliability, validity, confirmatory factor analysis (CFA), and structural equation modeling (SEM) procedures. The results of analyzes reveal six valid dimensions (facility, personnel, reliability, empathy, responsiveness, and accessibility and maintenance) and indicate significant relationship between fitness related service dimensions and satisfaction and intention as dependent variable.

Key Words: Fitness, Fitness Services, Quality, Fitness Quality, Fitness Services Quality

Doi: 10.17363/SSTB.20151610875

(1) Sorumlu Yazar: Hüseyin KÖSE, Anadolu University Faculty of Sport Sciences Eskişehir / Türkiye huseyink@ anadolu.edu.tr Geliş Tarihi / Received: 30.12.2014 Düzeltme Tarihi / Revision Date 09.02.2015 Kabul Tarihi/ Accepted: 20.04.2015 Makalenin Türü: Type ofarticle (Araştırma - Uygulama / Research -Application) Çıar Çatısması / Conflict of Interest:Yok / None "Etik Kurul Raporu Yok - None Ethics Committee" 


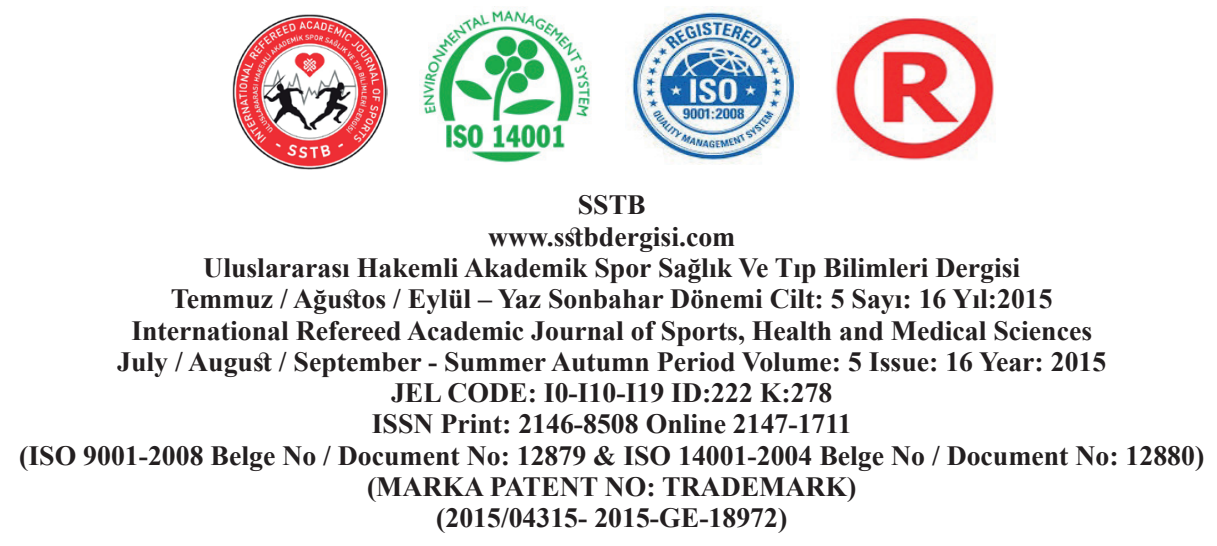

\section{INTRODUCTION AND LITERATURE}

In the current dramatically changing market environment, service quality is the key to attaining competitive advantages for fitness organizations. Service quality continues to gain popularity among the many service companies throughout the world. Moreover, in a competitive based condition, service quality and its effect on satisfaction and attitudinal or behavioral intention is the key to competing long times. Numerous studies have established the link between service quality, satisfaction and loyalty. Service quality has received an increasing interest worldwide due to its positive impact on satisfaction and loyalty. This study investigates the role of fitness-related quality in shaping satisfaction and intention. Service quality is widespread, particularly for services related to business, health and marketing.

\section{Service Quality And Fitness Service Quality}

Service quality is considered one of the most important subjects in business management (Lin, 2010) and has been variously defined in numerous studies. Parasuraman et al. (1988) defined service quality as a global judgment or attitude relating to the superiority of a service. Rust and Oliver (1993) stated service quality as the consumer's overall impression of the relative superiority of the service of an organization. According to traditional and more accepted approach it is the difference between customer expectation and perception of the provided service and conceptualized as a customer's evaluation of the perceived performance of the service compared to the expectations they held for that service (Parasuraman et al., 1985; Zeithaml et al., 1996; Lin, 2010; Smith et al., 2014). And recently service quality has become great differentiator between organizations and is one of the most powerful weapons that many leading service organizations possess (Lotz, 2009; Soita, 2012).

Service quality has been linked to outcomes such as customer satisfaction, customer loyalty and repurchases intention (Soita, 2012). High service quality makes the customers satisfied and loyal, thus they continue to buy services, increase the volume of their purchases and engage in positive WOM (wordof-mouth) publicity (Howat et al., 1999). To satisfy customers, service quality allows managers to identify strengths and areas for improvement of attributes of the service that they can manage to help improve their competitive advantage (Senekham, 2008). On the one hand, when customers' perceptions of service quality are positive, the behavioral intentions are favorable, which strengthens their relationship with the organization (Zeithaml and Bitner, 2003), on the other hand, when customers' perceptions are negative, the behavioral intentions are unfavorable, which 


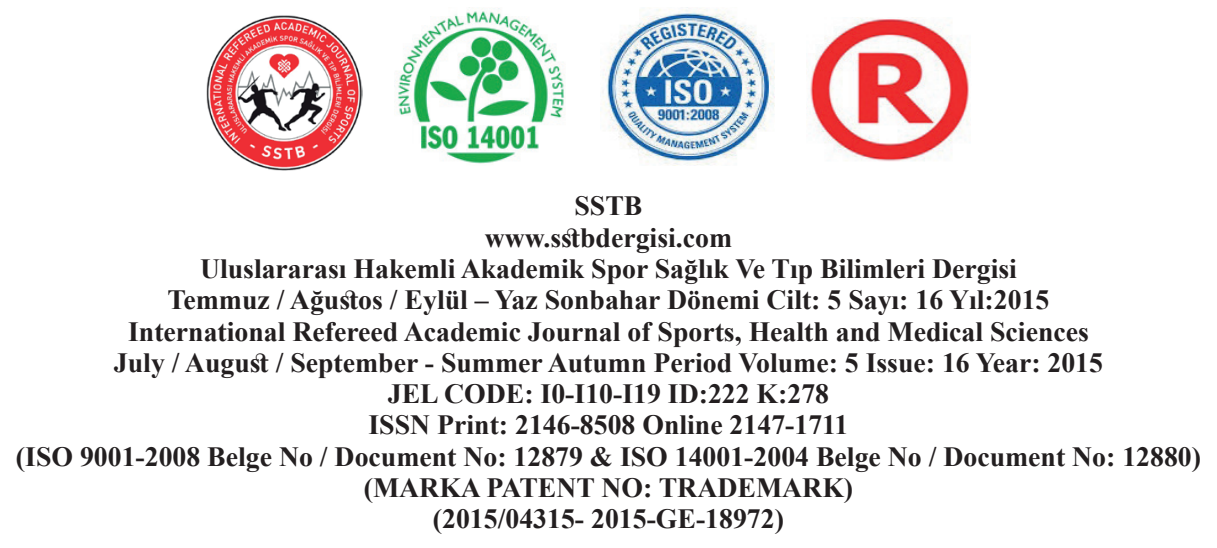

weakens their relationship with the organization (Kouthouris and Alexandris, 2005). Any failure about service quality ends up with customer defections that have a surprisingly powerful impact on organizations profits, market share, unit costs, and many other factors associated with competitive advantage. Also, it leads to loss of customer loyalty and low employee morale and high absenteeism (Soita, 2012).

A considerable body of research in the literature has focused on the nature of service quality and there is a general acceptance that service quality is composed of a number of underlying dimensions (Murray and Howat, 2002). To exact the nature of these dimensions and to measure perceptions of service quality Parasuraman et al., (1988) developed a 22-item instrument and named SERVQUAL, to be used in a variety of service industries. The researchers (Parasuraman, Ziethaml and Berry, 1988) have determined five determinants of service quality that may relate to any service: assurance, tangibles, reliability, responsiveness and empathy. Assurance refers to employees' knowledge and ability to convey trust and confidence; tangibles refers to an organization's physical environment, like facilities, equipment etc.; reliability refers to an organization's ability to perform the promised service accurately and dependably; responsiveness refers to employees' willing- ness to help customers; and empathy refers to employees' willingness to provide individualized attention to customers (Kouthouris and Alexandris, 2005). SERVQUAL scale has been empirically tested in numerous studies. For example, Babakus and Mangold (1992) used the scale in hospital service environment, in recreational services (Crompton and Mackay, 1989) and retailing in department stores (Finn and Lamb, 1991). Also, there have been many studies conducted on service quality in different business contexts and organizations. For example in local telephone services (Bolton and Drew, 1991), transportation (Bitner, 1990), health care and nursing (Donabedian, 1997), medical care (Donabedian, 2005), leisure (Murray and Howat, 2002; Howat et al., 2008), tourism (Baker and Crompton, 2000), shopping and dining ( $\mathrm{Wu}, 2014)$ etc. It's been a long time since health and fitness industry has witnessed a tremendous growth in interest and participation and has been a rapidly growing business on all over the world for many years (Senekham, 2008). Competitive marketing for those industries to attract customers has been increasing. Delivery of superior services is stated as a perquisite for long-term success (Parasuraman et al., 1985). As Llyod and Luk (2011) stated superior service quality leads to improved levels of customer satisfaction and satisfied customers remain loyal to the organization (Smith et al., 2014). For fitness 


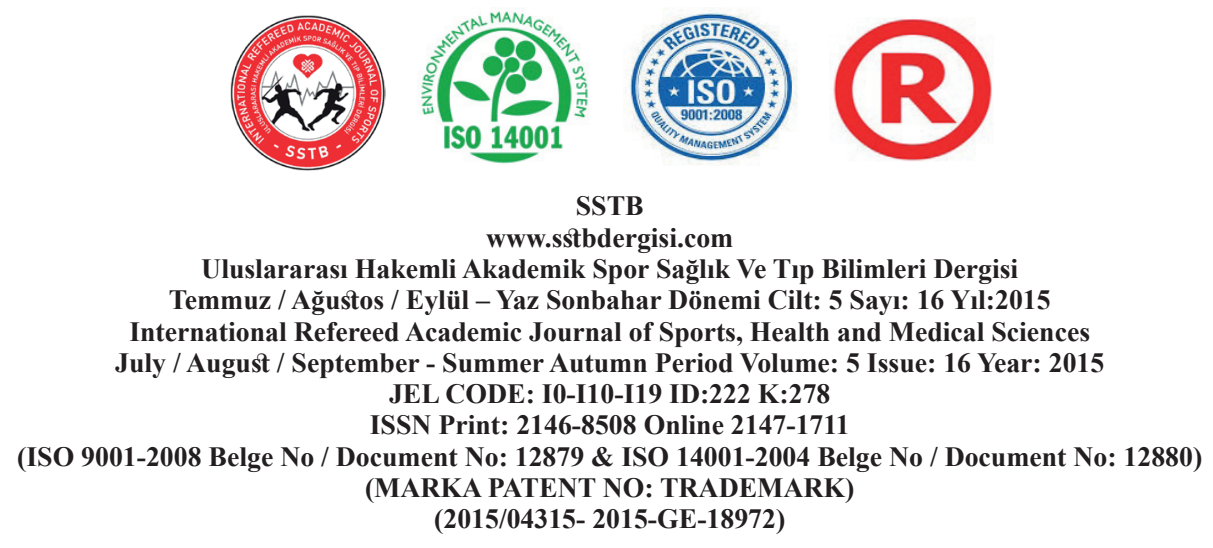

club managers and marketers, retention of members and measuring their loyalty are increasingly important. Many studies revealed that high service quality is the key factor for retention of customers and profitability (Fornell and Wernerfelt, 1987; Parasuraman et al., 1988, Zeithaml and Bitner, 2003; Alexandris et al., 2004; Lam et al., 2005; Senekham, 2008).

Services in fitness clubs require physical interaction between the provider and the customers; the services presented in the fitness clubs are complex and distinctive (Chang and Chelladurai, 2003). Therefore it is important for fitness club managers and service-providers understand their participants' wants and needs (Lagrosen and Lagrosen, 2007) because they spend long time in receiving the fitness service relative to conventional services. A unique feature of the service given in the fitness club is the members' involvement in the production and consumption of the services (Chang and Chelladurai, 2003). Membership dues are one of the major sources of revenue for fitness clubs, thus member retention is very important to the financial status of the clubs. Members' loyalty to the clubs is related to their perception of the service quality. So, measuring and evaluating fitness clubs service quality is necessary to meet the needs and expectations of the participants (Lam et al., 2005).
Relationship Among Service Quality, Customer Satisfaction, And Purchase Intention

As mentioned above, service quality is an important topic attracted significant attention by researchers in the marketing literature, since service quality perceptions are related with customer satisfaction (Parasuraman et al., 1988; Alexandris et al., 2004; Lam et al., 2005). Zeithaml and Bitner (2003) described satisfaction as a judgment that a product or service itself provides a pleasurable level of consumption related fulfillment. Also the authors underlined that assessment of satisfaction focuses specifically on service quality dimensions. So customers' perception of service quality influences their satisfaction. Customers' positive perceptions about the interaction, physical environment and outcomes of service quality are likely to report high levels of satisfaction (Alexandris et al., 2004). Satisfied customers are more likely to become involved more frequently and to take part in the services offered by the organization, to pay for the benefits that they receive and to be more tolerant of price increases (Lam et al., 2005).

Studies in service marketing literature have suggested that service quality perceptions and customer satisfaction influence customers' purchase intentions (Chang, 1998) and numerous studies have identified the critical roles of service quality on purchase intention 


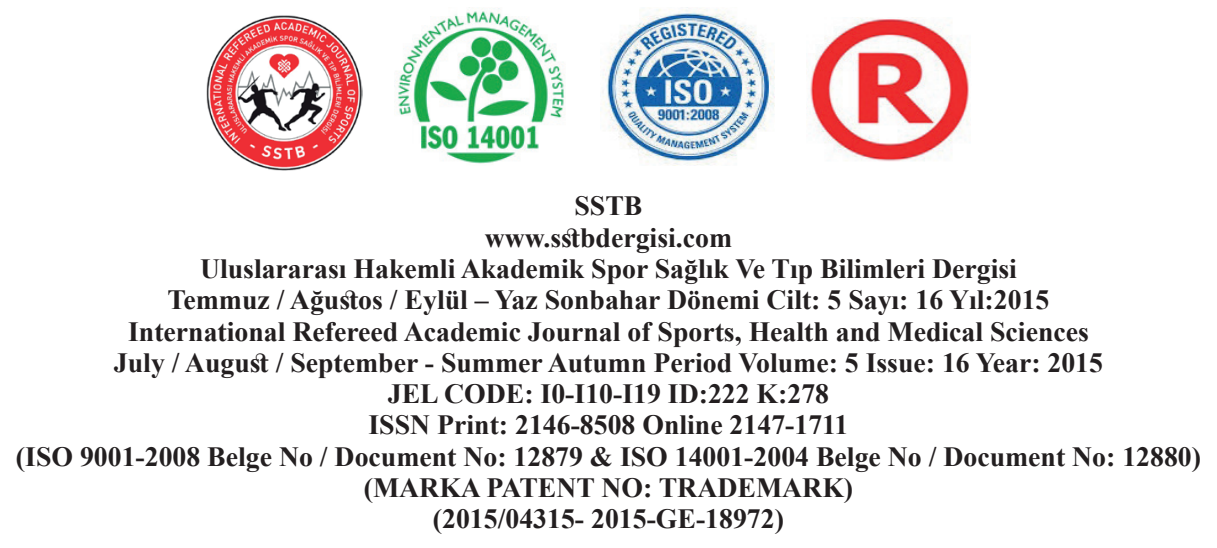

(Cronin and Taylor, 1992; Taylor and Baker, 1994; Chang, 1998). As Taylor and Baker (1994) stated high levels of service quality and high levels of satisfaction result in high levels of purchase behavior. Also, according to Oliver (1997) and Lin (2010) positive attitudes to any specific brand or organization in customers' mind positively contribute to the intention of repurchase. Many studies (Newman and Werbel, 1973; Taylor and Baker, 1994; Alexandris et al., 2004; Lin, 2010) have underlined that there is a high association among customer satisfaction and repurchase intention. Customers who are satisfied by the service quality are more likely to express an intention to remain loyal and say positive things about the organization to other potential customers (Zeithaml et al., 1996). As Murray and Howat (2002) stated there has been considerable debate whether satisfaction is an antecedent to, or a consequence of, service quality, or if they are distinct to each other (Crompton and MacKay, 1989; Oliver, 1993) and there's also evidence to suggest that it is the customer satisfaction which ultimately determines future intentions of customers and behaviors towards the organization (Taylor and Baker, 1994). In some models proposed in the literature (Cronin and Taylor, 1992; Zeithaml and Bitner, 2003) have stated that satisfaction as an intervening variable between service quality and behavioral intentions. But there are also some researches
(Baker and Crompton, 2000; Tian-Cole et al., 2002) reporting that service quality perceptions can have a direct influence on behavioral intentions. Also, there is some evidence that service quality perceptions are related to positive behavioral intentions and positive word-of-mouth publicity (Alexandris et al., 2001).

It is important for fitness club managers to understand the importance of service environment in satisfying and retaining their members. Service quality is one of the key factors that affect profitability of fitness organizations. In recent years, a considerable body of research (Chang, 1998; Howat et al., 1999; Murray and Howat, 2002; Alexandris et al., 2004; Lam et al., 2005; Lagrosen and Lagrosen, 2007; Lotz, 2009; Lin, 2010; Yu et al., 2014) has been made to understand service quality associated with sport clubs and sport facilities. However there is no or a little research conducted on service quality in fitness organizations in Turkish literature. It is important and necessary to understand customers' assessment of service quality, customer satisfaction and repurchase intention and relationships among these three variables, because they are the core factors (Yu et al., 2014) concerning the effectiveness of fitness clubs and organizations. Therefore, the purpose of the current study is to reveal the dimensions related to service quality of fit- 


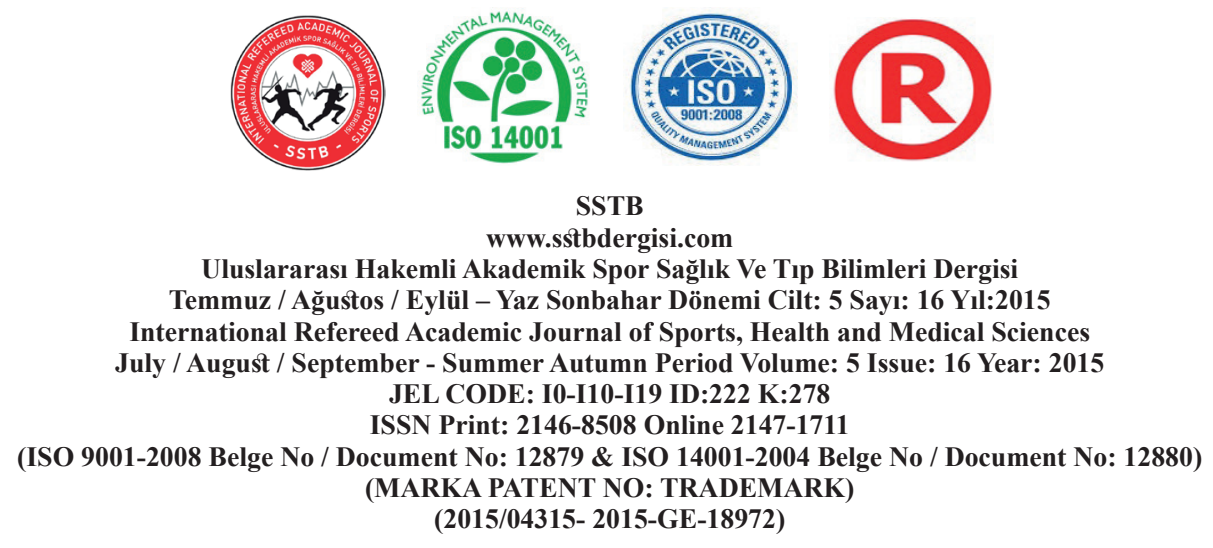

ness centers and analyze the effects of fitness service quality on satisfaction and repurchase behavior to gain insightful information and provide more effective services to customers in fitness clubs and organizations.

\section{METHODOLOGY}

The study involved a quantitative research methodology employing a questionnaire and convenience sampling with members of a private fitness center within a city (Eskisehir) in the middle region of the Turkey. A questionnaire applied in this study. Primarily, the questionnaire was pre-tested on a convenience sample of 22 fitness club members living in Eskisehir, Turkey. Then it was administrated to people who were members of private fitness center in Turkey between March 2014 and May 2014. Each person answered the questionnaire individually. The survey lasted around 15 minutes. A total of 233 questionnaires have been administrated. The questionnaire comprised three parts. The first part contained 24 statements related to dimensions of service quality in fitness centers. The items in the first part were developed and adapted from existing literature (e.g., Kim and Kim, 1995; Lim, 2006; MacKay and Crompton, 1990; Parasuraman et al., 1988). The scale of satisfaction and intention in the second part was adapted from Oliver (1997) and Zeithaml et al. (1996). All fitness club members filled in the questionnaire individu- ally and respondents were asked to indicate on a 5-point scale to what extent they agree $(5=$ strongly agree, $1=$ strongly disagree $)$ with each item in the first and second part of questionnaires. The last part of questionnaire was designed to collect the reasons of fitness participation and demographic characteristics of respondents.

\section{FINDINGS}

Table 1 presents the fitness participation reasons and demographic characteristics of the sample by gender, age, educational level, and income. There were $52.8 \%$ male and 47.2 were female. The average age of the respondents was 31 years (S.D: 8.5 , range $=$ 16-58). Approximately, half of them (47.2\%) were between 26 and 35 years. Most of the respondents had university degree $(72.6 \%)$, and $14.6 \%$ had high school degree. With regard to the household monthly income of respondent, about one-third of participants was at 1317-1974 USD. Approximately 20\% of the participants were students, $15.9 \%$ of them were public officials, and $12 \%$ of them were self-employed. More than half of respondents $(57.5 \%)$ reported they were members of fitness club since a year. According to the mean scores, health $(\mathrm{M}=4.84 ; \mathrm{SD}=0.46)$ and sport $(\mathrm{M}=4.49 ; \mathrm{SD}=0.84)$ were main reasons for fitness among participants. 
SSTB

www.sstbdergisi.com

Uluslararası Hakemli Akademik Spor Sağlık Ve Tıp Bilimleri Dergisi

Temmuz / Ağustos / Eylül - Yaz Sonbahar Dönemi Cilt: 5 Sayı: 16 Yıl:2015

International Refereed Academic Journal of Sports, Health and Medical Sciences

July / August / September - Summer Autumn Period Volume: 5 Issue: 16 Year: 2015

JEL CODE: I0-I10-I19 ID:222 K:278

ISSN Print: 2146-8508 Online 2147-1711

(ISO 9001-2008 Belge No / Document No: 12879 \& ISO 14001-2004 Belge No / Document No: 12880)

(MARKA PATENT NO: TRADEMARK)

(2015/04315- 2015-GE-18972)

Table 1. Characteristics Of The Respondents And Fitness Participation ( $N=\mathbf{2 3 3})$

\begin{tabular}{|c|c|c|c|c|c|}
\hline & Frequency & $\%$ & & Frequency & $\%$ \\
\hline Gender & & & Occupation & & \\
\hline Male & 123 & 52.8 & Student & 47 & 20.2 \\
\hline Female & 110 & 47.2 & Housewife & 7 & 3.0 \\
\hline Age & & & Tradesman & 14 & 6.0 \\
\hline 25 and $<$ & 65 & 27.9 & Public Official & 37 & 15.9 \\
\hline $26-35$ & 111 & 47.6 & Worker & 15 & 6.4 \\
\hline 36 and $>$ & 57 & 24.5 & Manager & 17 & 7.3 \\
\hline Education Level & & & Instructor & 14 & 6.0 \\
\hline Secondary school or less & 2 & 0.8 & Retired & 10 & 4.3 \\
\hline High school & 34 & 14.6 & Self-employed & 28 & 12.0 \\
\hline University & 169 & 72.6 & Other & 44 & 18.9 \\
\hline Post Graduate & 28 & 12.0 & Membership Year & & \\
\hline Household Income & & & 1 & 134 & 57.5 \\
\hline $658 \$$ and $<$ & 38 & 16.3 & 2 & 62 & 26.6 \\
\hline $659-1316 \$$ & 69 & 29.6 & 3 & 23 & 9.9 \\
\hline 1317-1974 \$ & 77 & 33.0 & 4 and $>$ & 14 & 6.0 \\
\hline $1975-2632 \$$ & 25 & 10.7 & Reasons of Fitness & $M^{*}$ & $S D$ \\
\hline \multirow[t]{6}{*}{$2633 \$$ and $>$} & 24 & 10.4 & Health & 4.84 & 0.46 \\
\hline & & & Sport & 4.49 & 0.84 \\
\hline & & & Slimming & 4.18 & 1.01 \\
\hline & & & Leisure & 3.11 & 1.44 \\
\hline & & & Socialization & 2.90 & 1.56 \\
\hline & & & Competition & 2.20 & 1.29 \\
\hline
\end{tabular}

Fitness Service Quality

In this study, the data were subjected to reliability, validity, confirmatory factor analy- sis (CFA), and structural equation modeling (SEM) procedures. Prior to CFA, both univariate and multivariate non-normality were examined. Univariate non-normality was 


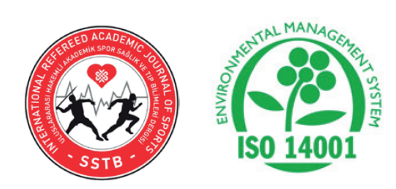

SSTB

www.sstbdergisi.com

Uluslararası Hakemli Akademik Spor Sağlık Ve Tıp Bilimleri Dergisi

Temmuz / Ağustos / Eylül - Yaz Sonbahar Dönemi Cilt: 5 Sayı: 16 Yıl:2015

International Refereed Academic Journal of Sports, Health and Medical Sciences

July / August / September - Summer Autumn Period Volume: 5 Issue: 16 Year: 2015

JEL CODE: I0-I10-I19 ID:222 K:278

ISSN Print: 2146-8508 Online 2147-1711

(ISO 9001-2008 Belge No / Document No: 12879 \& ISO 14001-2004 Belge No / Document No: 12880)

(MARKA PATENT NO: TRADEMARK)

(2015/04315- 2015-GE-18972)

tested using skewness and kurtosis. To assume normality, Kline (1998) suggested cut off absolute values of 3.0 and 8.0 for skewness and kurtosis respectively. However, West et al. (1995) have suggested a stricter standard of 2.0 and 7.0. The extreme among all the variables was 2.12 for kurtosis and -1.62 for skewness for one variable, which was within the acceptable limits (Kline, 1998). After the normal distribution testing, a CFA was employed in order to ascertain the factor structure, using LISREL 8.80 (Jöreskog and Sörbom, 2006). The ratio of $\chi^{2} / \mathrm{df}$ was used to assess the overall fit of the model. The ratio of $\mathrm{X}^{2} / \mathrm{df}(2.75 ; \mathrm{p}<0.01)$ was satisfactory indicating below the cut-off point 3 (Kline, 2005).

It is commonly accepted that chi-square statistic will reject valid models in large samples (Baggozi and Yi, 1988); therefore, the many researchers (e.g., Chin, 1998; Longo and Mura, 2007) relied on the goodness-offit (GFI), the comparative fit index (CFI), the incremental fit index (IFI), the non-normed fit index (NNFI), the standardized root mean square residual (SRMR), and the root mean square error of approximation (RMSEA). SRMR and RMSEA measure the poorness of fit (Lee et al., 2007). Brown and Cudeck
(1992) suggested that RMSEA values of less than 0.06 indicate good fit, values of 0.08 or less would represent reasonable fit and values higher than 0.10 indicate poor fit (Brown and Cudeck, 1992). CFI and NNFI indicate how much better the hypothesized model fits compared to the base model. Any value greater than 0.90 in CFI and NNFI indexes indicates an acceptable fit with the data $\mathrm{Hu}$ and Bentler, 1999). Table 2 shows the fit values of the model and results suggests that six-factor analysis provides the best fit (CFI $=0.96, \mathrm{NFI}=.94, \mathrm{RMSEA}=0,08)$ for fitnessrelated quality.

In the current study, the RMSEA value of 0.084 was well below 0.1 or approximately equal to 0.08 , indicating a low discrepancy between the implied covariance in the model and observed covariance in the data ( $\mathrm{Li}, \mathrm{Liu}$ and Zhao, 2006).

In addition, the SRMR value (0.070) was also below the 0.08 . Four of all six incremental fit indices $(\mathrm{GFI}=0.77, \mathrm{AGFI}=0.73, \mathrm{NFI}=0.94$, $\mathrm{NNFI}=0.96, \mathrm{CFI}=0.96, \mathrm{IFI}=0.96)$ met or exceeded the preferred level of 0.9 (Gefen et al., 2000; Soto-Acosta and o-Cerdan, 2008). Only GFI and AGFI were less than required level. 


\section{Table 2. Fitness-Related Quality Factors}

\begin{tabular}{|c|c|c|c|c|}
\hline CONSTRUCTS & $\begin{array}{c}\text { Std. } \\
\text { Loadings }\end{array}$ & CR & AVE & $\begin{array}{l}\text { Construct } \\
\text { Reliability }\end{array}$ \\
\hline Facilities & & 0.89 & 0.54 & 0.87 \\
\hline The facility is generally clean & 0.76 & & & \\
\hline Shower facilities are adequate & 0.71 & & & \\
\hline Shower areas are clean & 0.77 & & & \\
\hline Lockers are sufficient & 0.77 & & & \\
\hline Hair dryers are sufficient & 0.67 & & & \\
\hline Recreational areas are suitable & 0.64 & & & \\
\hline Personnel & & 0.84 & 0.52 & 0.83 \\
\hline Facilities are modern and attractive & 0.68 & & & \\
\hline Facilities are comfortable for usage & 0.70 & & & \\
\hline Employees are suitable clothes and good looks & 0.73 & & & \\
\hline Employees makes the task well & 0.72 & & & \\
\hline Employees are kind & 0.76 & & & \\
\hline Reliability & & 0.83 & 0.54 & 0.81 \\
\hline The information given is correct & 0.75 & & & \\
\hline The promises are kept & 0.67 & & & \\
\hline Employees are reliable & 0.79 & & & \\
\hline Employees are expert & 0.73 & & & \\
\hline Empathy & & 0.89 & 0.74 & 0.88 \\
\hline Employees are willing & 0.80 & & & \\
\hline Employees pay special attention to members & 0.90 & & & \\
\hline Staff understands the needs of members & 0.87 & & & \\
\hline Responsiveness & & 0.87 & 0.70 & 0.83 \\
\hline Problems are resolved quickly & 0.71 & & & \\
\hline $\begin{array}{l}\text { Fitness managers are eager to implement of members' } \\
\text { proposals }\end{array}$ & 0.89 & & & \\
\hline Managers are friendly and open to new ideas & 0.83 & & & \\
\hline
\end{tabular}




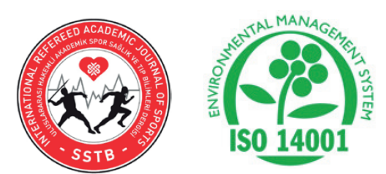

SSTB

www.sstbdergisi.com

Uluslararası Hakemli Akademik Spor Sağlık Ve Tıp Bilimleri Dergisi

Temmuz / Ağustos / Eylül - Yaz Sonbahar Dönemi Cilt: 5 Sayı: 16 Yıl:2015

International Refereed Academic Journal of Sports, Health and Medical Sciences

July / August / September - Summer Autumn Period Volume: 5 Issue: 16 Year: 2015

JEL CODE: I0-I10-I19 ID:222 K:278

ISSN Print: 2146-8508 Online 2147-1711

(ISO 9001-2008 Belge No / Document No: 12879 \& ISO 14001-2004 Belge No / Document No: 12880)

(MARKA PATENT NO: TRADEMARK)

(2015/04315- 2015-GE-18972)

\begin{tabular}{|c|c|c|c|c|}
\hline Accessibility and Maintenance & & 0.74 & 0.49 & 0.72 \\
\hline The spa area is clean and well maintained & 0.63 & & & \\
\hline It is easy access to fitness center & 0.67 & & & \\
\hline Fitness equipment is new and well-maintained & 0.78 & & & \\
\hline Satisfaction and Intention & & 0.93 & 0.73 & 0.91 \\
\hline This fitness center has everything that should be in a facility & 0.83 & & & \\
\hline Services provided in this center are sufficient. & 0.75 & & & \\
\hline This fitness center did meet my expectations. & 0.89 & & & \\
\hline I am happy with this facility. & 0.90 & & & \\
\hline I would recommend this resort to my friends & 0.88 & & & \\
\hline I think that I will renew my membership & 0.79 & & & \\
\hline \multicolumn{5}{|c|}{$\begin{array}{l}\chi 2=1093,73(\mathrm{p}=0,000), \mathrm{df}=398, \chi 2 / \mathrm{df}=2,75, \mathrm{RMSEA}=0,084, \mathrm{GFI}=0.77, \mathrm{AGFI}=0.73, \mathrm{NFI}=0.94, \mathrm{NNFI} \\
=0.96, \mathrm{CFI}=0.96, \mathrm{IFI}=0.96, \mathrm{SRMR}=0.070\end{array}$} \\
\hline
\end{tabular}

Table 2 displays factor loadings, composite reliability (CR), construct reliability coefficients (alpha), and average variance extracted (AVE) values. All factor loadings were positive and significant $(\mathrm{p}<0.01)$ ranging from 0.63 to 0.90 . Cronbach's alpha analysis of the factors revealed alphas ranging from 0.72 to 0.91 , indicating acceptable reliability of the instruments. All reliability coefficients were higher than the recommended criteria of 0.70 (Kline, 2005). Also, alpha for scale of fitnessrelated quality (24 items) was 0.92 , and for satisfaction and intention scale was 0.91 , indicating high acceptance level. Fornell and Larcker (1981) suggest a CR value of more than 0.6. As Table 2 shows, the $\mathrm{CR}$ value of each variable was more than 0.74 , indicating acceptable internal consistency (Hair et al.
2006). Two criteria were used to evaluate the convergent validity of the scales as suggested by Fornell and Larcker (1981). First, the indicator's estimated coefficient should be significant on its posited underlying construct. All the loadings on the hypothesized constructs were significant and exceeded 0.63. Second, AVE values were used to assess how well the items on a specific subscale accounted for the underlying construct's variance. The AVE values above 0.50 indicate that the items collectively explain the adequate amount of variance in the underlying construct (Hair et al., 2005). The results in Table 2 demonstrate that the AVE values exceeded .49 for all constructs, in support of the convergent validity of our survey instrument (Fornell and Larcker 1981). Clearly, the results indicated that 


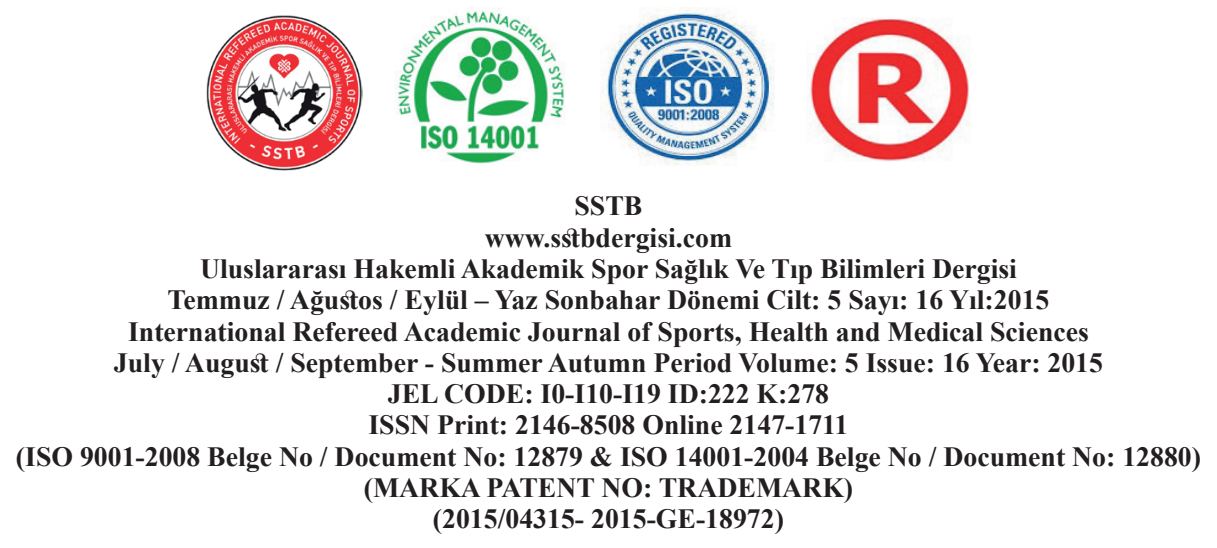

five of six AVE values of this study model are higher than 0.50 , the standard value suggested by Fornell and Larcker (1981) and Hair et al. (2005). Besides, the discriminant validity is determined by verifying that the average variance of each variable is greater than the relationship value of each pair of variables by 50 percent (Fornell and Larcker, 1981). The average variance of the variables in this study is greater than the relationship value of each pair of variables, indicating sufficient discriminant validity. Finally, all pairs of construct showed a correlation coefficient that was significantly different from 1.0, indicating discriminant validity (Anderson and Gerbing, 1988). Altogether, these results allow for the researchers to provide evidence that the instruments used in this study measured the constructs of interest with strong reliability and validity. The results of CFA revealed that the factors related with fitness service quality could be examined in six dimensions. These factors titled 'facility', 'personnel', 'reliability', 'empathy', 'responsiveness', and 'accessibility and maintenance'.
Total explained variance in fitness- related scale was $69.110 \%$.

Relationship Between Fitness Quality And Satisfaction

Table 3 shows the model's path coefficients and model fit indexes. The model fit indexes equaled or exceed their respective common acceptance levels, indicating that the displayed fitted the data well. The chi-square is significant $\left(X^{2}(398)=1052,68, p<0.01\right)$, which is usually the case for large sample sizes and the ratio of $\mathrm{X}^{2} / \mathrm{df}(2.90)$ was satisfactory indicating below the cut-off point 3 (Kline, 2005).

All but two of the statistics are within the acceptable ranges, indicating a good fit to the data. Except GFI and AGFI values, other model fit indices were indicative of a good fit of the model to the data (CFI $=0.94$, NNFI $=0.96$, IFI $=0.96$ ). Similarly, RMSEA value (0.084) was about equal of cut-off value 0.08 , and index of SRMR (0.070) was bellow of the acceptance level 0.08 .was bellow of the acceptance level 0.08. 


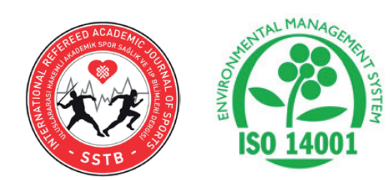

SSTB

www.sstbdergisi.com

Uluslararası Hakemli Akademik Spor Sağlık Ve Tıp Bilimleri Dergisi

Temmuz / Ağustos / Eylül - Yaz Sonbahar Dönemi Cilt: 5 Sayı: 16 Yıl:2015

International Refereed Academic Journal of Sports, Health and Medical Sciences

July / August / September - Summer Autumn Period Volume: 5 Issue: 16 Year: 2015

JEL CODE: I0-I10-I19 ID:222 K:278

ISSN Print: 2146-8508 Online 2147-1711

(ISO 9001-2008 Belge No / Document No: 12879 \& ISO 14001-2004 Belge No / Document No: 12880)

(MARKA PATENT NO: TRADEMARK)

(2015/04315- 2015-GE-18972)

Table 3. Results For Structural Model

\begin{tabular}{lcc}
\hline & Standardized Solution & $t$-Value \\
\hline $\mathrm{SQ} \rightarrow$ Satisfaction and Intention & 0.87 & 12.26 \\
\hline$\chi 2=1052,68(\mathrm{p}=0,000), \mathrm{df}=398, \chi 2 / \mathrm{df}=2,64, \mathrm{RMSEA}=0,084, \mathrm{GFI}=0.77, \mathrm{AGFI}=0.73$, \\
$\mathrm{NFI}=0.94, \mathrm{NNFI}=0.96, \mathrm{CFI}=0.96, \mathrm{IFI}=0.96, \mathrm{SRMR}=0.070$
\end{tabular}

Findings reported in Table 3, according to the standardized beta coefficients and t-values, confirm that the together six factors related with fitness quality was the best predictor of satisfaction and intention.

\section{CONCLUSIONS}

The main goal of the current study was to measure quality dimensions within private fitness context. The current study assessed the quality factors in private fitness centers and its association with satisfaction and intention among members of a private fitness center in a city of middle region in Turkey. As well as, the study was designed to examine the relationship between two measures: The perceived fitness service quality scale and satisfaction with fitness service and behavioral intention scale.

The results revealed that the factors related with fitness service quality could be examined in five dimensions. These factors named 'facility', 'personnel', 'reliability', 'empathy', and 'accessibility and maintenance'. These results confirmed previous findings for service quality dimensions for fitness, which claimed that personnel, tangibles, equipment, facility design, empathy, responsiveness, accessibility, ambient conditions, assurance were very important as fitness quality indicators.

There was a strong and statistically significant positive effect of fitness service quality on satisfaction. The results of SEM indicate that there are meaningful relationships among fitness-related service quality and satisfaction. With regard to the dimensions of the fitness-related quality, it is concluded that one-dimensional structure of the quality affects the satisfaction and intention level, in contrast of separately. Further, because the relationship is significant, it is also safe to conclude that each measure is a valid instrument. These results confirm previous empirical findings for service-related business showing that satisfaction (Zeithaml et al., 1996), intention, word-of-mouth and, loyalty (Oliver, 1997; Smith et al., 2014) are influenced by high level service quality. Whilst fitness centers should be aware of perceived service quality dimensions on satisfaction and intention, it is important to note that long-term 


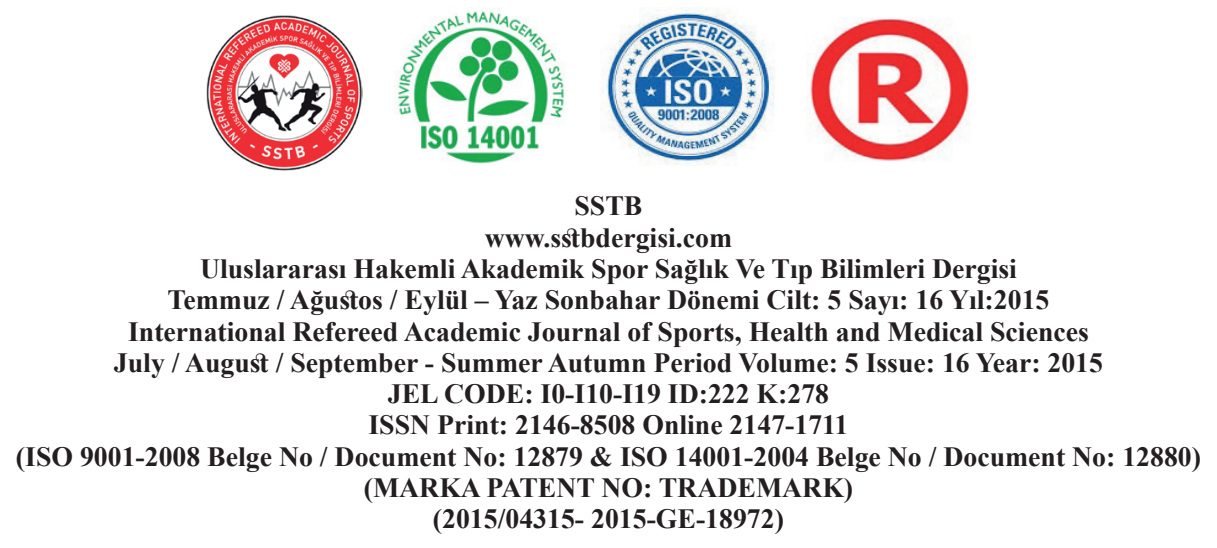

customer relationship strategies are effective in increasing the rate of the membership and profit.

As indicated by Zeithaml et al. (1996), service quality for many service organization has been recognized as important to long term profitability. Earlier studies have shown that perceived service quality is one of the strongest predictor of satisfaction (Oliver, 1997; Zeithaml et al., 1996) and intention. Also, as indicated by Alexandris et al. (2004), satisfaction have a strong influence on word-ofmouth communications. Satisfied members are likely to spread positive word-of-mouth about fitness club (Alexandris et al., 2004). Therefore, many organizations in different service industries rely on the eligibility of the service quality as satisfaction predictors. Therefore, corroborating previous research, the present results also showed that satisfaction in fitness services in Turkey depends on service quality perceptions. Superior fitness quality leads to improved levels of member loyalty, typically via increasing satisfaction of member with the fitness provider (Smith et al., 2014). It is assumed that high satisfaction level in services may provide a solid commitment for products (e.g., spinning, yoga, and zumba) of fitness centers. Thus, members who participated frequently in experimental fitness services has an increased likelihood of loyalty with brand of fitness center. On the other hand, members who rarely used the services of fitness centers are less likely to be loyal members.

In conclusion, the results of the study indicate six valid dimensions of fitness-related service quality. In addition, there are significant relationship between fitness quality and satisfaction with fitness services. In terms of success of fitness center, enforcement and renewal of the current services or launched new services are considered critical for success. Specifically, since members evaluate the fitness quality in terms of user perspective, the findings may serve as a potential pioneer for the organizational leadership or innovation. There are several implication for fitness managers. The manager has to be aware of several dimensions of fitness-related service quality. These six dimensions explain common facets of service quality in fitness centers. In addition, managers can evaluate their service operation both the service quality dimensions and the new equipment or fitness forms.

\section{LIMITATIONS AND FUTURE STUDIES}

There are some limitations to the current study. Therefore, the results of the current study should be interpreted in the light of a number of research limitations. A major weakness of this study is the small sample of members sampled from non-randomly selected private fitness center. So, members from only one 


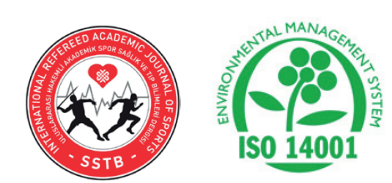

SSTB

www.sstbdergisi.com

Uluslararası Hakemli Akademik Spor Sağlık Ve Tıp Bilimleri Dergisi

Temmuz / Ağustos / Eylül - Yaz Sonbahar Dönemi Cilt: 5 Sayı: 16 Yıl:2015

International Refereed Academic Journal of Sports, Health and Medical Sciences

July / August / September - Summer Autumn Period Volume: 5 Issue: 16 Year: 2015

JEL CODE: I0-I10-I19 ID:222 K:278

ISSN Print: 2146-8508 Online 2147-1711

(ISO 9001-2008 Belge No / Document No: 12879 \& ISO 14001-2004 Belge No / Document No: 12880)

(MARKA PATENT NO: TRADEMARK)

(2015/04315- 2015-GE-18972)

private fitness center in Turkey participated in the study; findings from this study may not be generalizable to Turkey as a whole or to other parts of the country. Also limiting the generalizability of the study was the selected fitness center type, indicating high level of social-sportive club. The findings relative to the fitness center may not be applicable to other recreational or sport centers. Therefore, future research should examine a variety of fitness. Previous empirical evidence supports the positive linkage between the perceived fitness quality and the consumer satisfaction. Future studies may explore relationships between fitness service quality and fitness engagement, fitness involvement, and membership duration and membership types.

\section{ACKNOWLEDGEMENT}

This study was submitted as an oral presentation at Annual Tokyo Business Research Conference, 15-16 December 2014, Waseda University, Tokyo, Japan.

\section{REFERENCES}

\section{ALEXANDRIS, K. ZAHARIADIS, P.,} TSORBATZOUDIS, C., \& GROUIOS, G., (2004). An Empirical investigation of the relationships among service quality, customer satisfaction and physiological commitment in a health club context, European Sport Management Quarterly, 4, $36-52$
ANDERSON, J.C., \& GERBING, D. W., (1988). Structural equation modeling in practice: A review and recommended two-step approach. Psychological Bulletin, 103, 411-423

BAGOZZI, R.P., \& YI, Y., (1988). On the evaluation of structural equations models. Journal of the Academy of Marketing Science, 16 (1): 74-94

BAKER, D., \& CROMPTON, J., (2000) Quality, satisfaction and behavioural intentions. Annals of Tourism Research, 27(3), 785-804

BABAKUS, E., \& MANGOLD, W.G., (1992). Adapting the SERVQUAL scale to hospital services: An empirical investigation. HSR: Health Services Research, 26 (6), 768-786.

BITNER, M.J., (1990). Evaluating service encounters: The effects of physical surroundings on employee responses. Journal of Marketing, 54(2), 69-82.

BROWN, M.W., \& CUDECK, R., (1992). Alternatives ways of assessing model fit. Sociological Methods and Research, 21, 230-258.

BOLTON, R., \& DREW, J., (1991). A multistage model of customers' assessment of service qualityand value. Journal of Consumer Research, 17(4), 375-384 


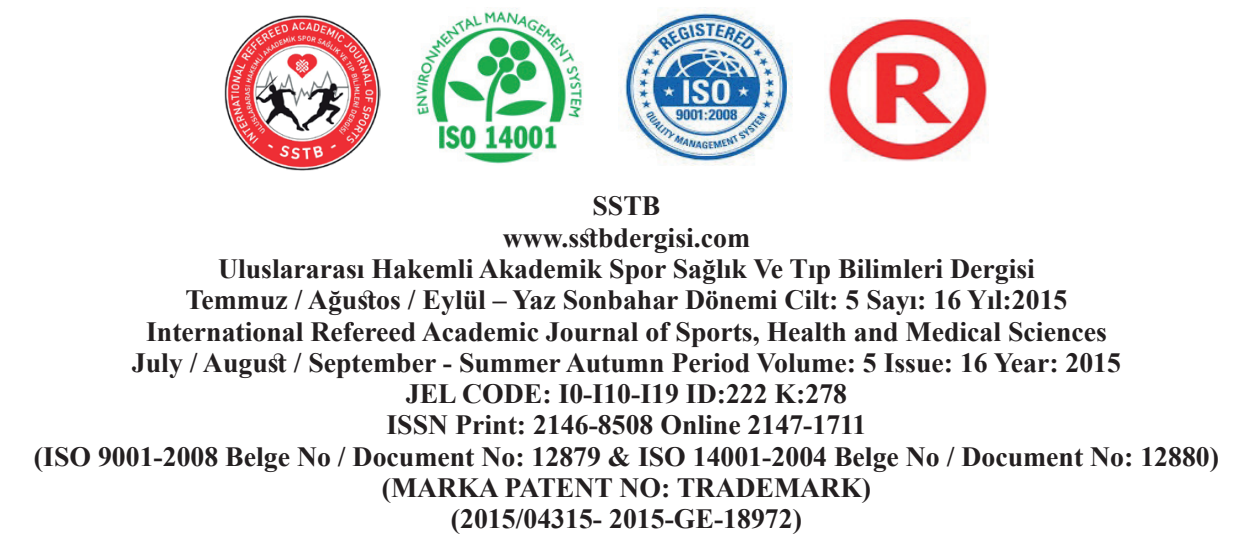

CHANG, K., (1998). A systems view of quality in fitness services: Development of a model and scales, Doctoral Dissertation, Ohio State University, Colombus

CHANG, K., \& CHELLADURAI, P., (2003). System-Based quality dimensions in fitness services: Development of the scale of quality, The Service Industries Journal, 23(5), 65-83

CHIN, W.W., (1998). Commentary: issues and option on structural equation modeling, MIS Quarterly, 20 (1), 7-16

\section{CROMPTON, J.L., \& MACKAY, K.J.,} (1989). Users' perceptions of the relative importance service quality dimensions in selected public recreation programs. Leisure Sciences, 11(4)

CRONIN, J.J., \& TAYLOR, S.A., (1992). Measuring service quality: A re-examination and extension. Journal of Marketing, 56(3), 55-68

DONABEDIAN, A., (1997). Special article: The quality of care: How can it be assessed? Archives of Pathology and Laboratory Medicine, 121(11), 1145-1150

DONABEDIAN, A., (2005). Evaluating the quality of medical care. The Milbank Quarterly, 83(4), 691 - 729
FINN, D.W., \& LAMB, C.W., (1991). An evaluation of the SERVQUAL Scales in Retailing Setting, Advances in Consumer Research, 18(1), 483-490.

FORNELL, C., \& DAVID, F.L., (1981). Evaluating Structural Equation Models with Unobservable and Measurement Error, Journal of Marketing Research, 18, $1,39-50$

FORNELL, C., \& WERNERFELT, B., (1987). Defensive marketing strategy by customer complaint management: A theoretical analysis. Journal of Marketing Research, 24(4), 337-346

GEFEN, D., STRAUB, D.W., \& BOUDREAU, M.C., (2000), Structural equation modeling and regression: Guidelines for research practice. Communications of the AIS, 4 (7), 1-78

HAIR, J.F., WILLIAM, C.B., BARRY, J., BABIN ROLPH E.A., \& RONALD, L.T., (2006). Multivariate Data Analysis. 6th ed. New Jersey: Prentice Hall

HAIR, J.F., BLACK, B., BABIN, B., ANDERSON, R.E., \& TATHAM, R.L., (2005). Multivariate data analysis (6th ed.). Upper Saddle River, NJ: Prentice Hall

HOWAT, G., MURRAY, D., \& CRILLEY, G., (1999). The relationships between 


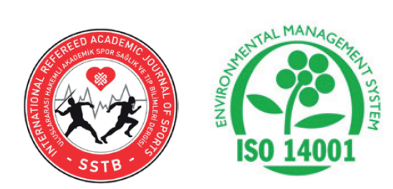

SSTB

www.sstbdergisi.com

Uluslararası Hakemli Akademik Spor Sağlık Ve Tıp Bilimleri Dergisi

Temmuz / Ağustos / Eylül - Yaz Sonbahar Dönemi Cilt: 5 Sayı: 16 Yıl:2015

International Refereed Academic Journal of Sports, Health and Medical Sciences

July / August / September - Summer Autumn Period Volume: 5 Issue: 16 Year: 2015

JEL CODE: I0-I10-I19 ID:222 K:278

ISSN Print: 2146-8508 Online 2147-1711

(ISO 9001-2008 Belge No / Document No: 12879 \& ISO 14001-2004 Belge No / Document No: 12880)

(MARKA PATENT NO: TRADEMARK)

(2015/04315- 2015-GE-18972)

service problems and perceptions of service quality, satisfaction and behavioral intentions of Australian public sports and leisure center customers, Journal of Park and Recreation Administration, 17(2), $42-64$

HOWAT, G., CRILLEY, G., \& MCGRATH, $\boldsymbol{R}$. , (2008). A focused service quality, benefits, overall satisfaction and loyalty model for public aquatic centers, Managing Leisure, 13, 139-161

HU, L., \& BENTLER, P.M., (1999). Cutoff criteria for fit indexes in covariance structure analysis: Conventional criteria versus new alternatives. Structural Equation Modeling, 6, 1-55

JÖRESKOG, K.G., \& SÖRBOM, D., (2006). LISREL 8.80 for Windows [Computer Software]. Lincolnwood, IL: Scientific Software International

KO, Y.J., \& PASTORE, D.L., (2005). A hierarchical model of service quality for the recreational sport industry. Sport marketing quarterly, 14, 84-97

KIM, D., \& KIM, S.Y., (1995). QUESC: An instrument for assessing the service quality of sport centers in Korea. Journal of Sport Management. 9, 208-220
KLINE, R.B., (2005). Principles and practice of structural equation modeling. New York. NY: Guilford Press

KOUTHOURIS, C., \& ALEXANDRIS, K., (2005). Can service quality predict customer satisfaction and behavioral intentions in the sport tourism industry? An application of the SERVQUAL model in an outdoors setting, Journal of Sport Tourism, 10(2), 101-111

LAGROSEN, S., \& LAGROSEN, Y., 2007, Exploring service quality in the health and fitness industry, Managing Service Quality: An International Journal, 17(1), 41-53

LAM, E.T.C., ZHANG, J., \& JENSEN, B.E., (2005). Service quality assessment scale (SQAS): An instrument for evaluating service quality of health-fitness clubs. Measurement in Physical Education and Exercise Science, 9(2), 79-111

LEE, J., GRAEFE, A.R., \& BURNS, R.C., (2007). Examining the Antecedents of Destination Loyalty in a Forest Setting. Leisure Sciences, 29, 463-481

LI, Y. LIU, Y., \& ZHAO, Y., (2006). The role of market and entrepreneurship orientation and internal control in the new product development activities of Chinese 


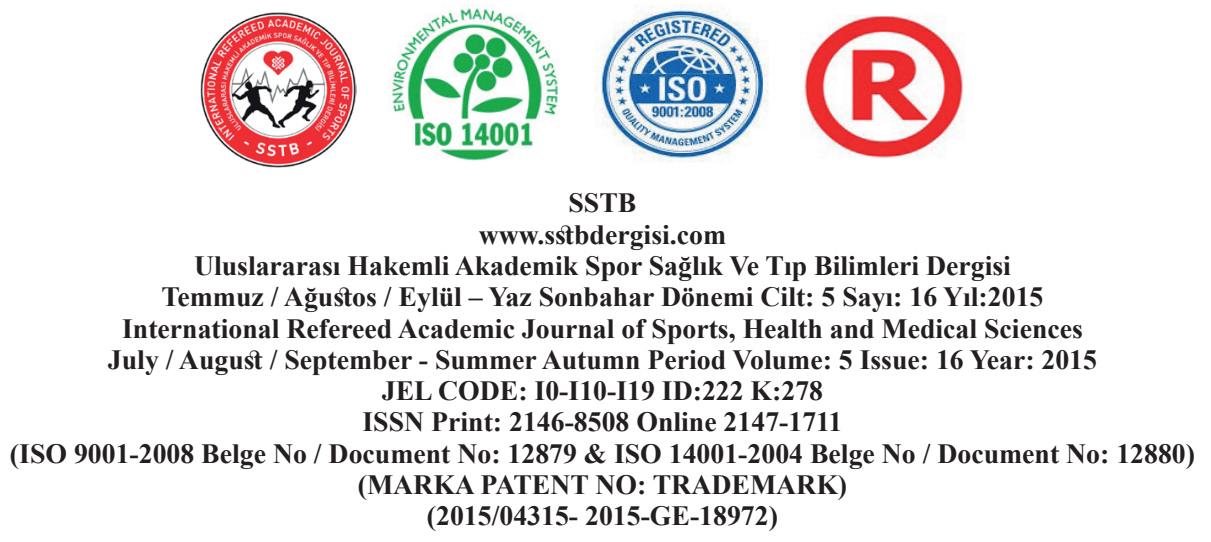

firms. Industrial Marketing Management, 35: $336-347$

tation, Durban University of Technology, Durban

LIM, S.J., (2006). The Influence of Service Quality on Customer Satisfaction, Attitudinal Loyalty, and Behavioral Future Intentions for Participation of Fitness Centers in South Korea: A structural equation modeling approach. Unpublished doctoral dissertation, United States Sports Academy, USA

LIN, H., (2010). The study of exercise participation motivation and the relationship among service quality, customer satisfaction, and customer loyalty at selected fitness health clubs in Taipei City, Taiwan. Doctoral Dissertation, Faculty of the United States Sports Academy, Alabama

LLOYD, A.E., \& LUK, S.T.K., (2011). Interaction behaviors leading to comfort in the service encounter. Journal of Services Marketing, 25(3), 176-189

LONGO, M., \& MURA, M., (2007). A multidimensional measure of employees' intangibles. A managerial implementation of the tool. Management Research News, 30 (8), 548-569

LOTZ, C., (2009). Customer service quality at selected commercial health and fitness centers in Kwazulu-Natal. Master disser-

MURRAY, D., \& HOWAT, G., (2002). The relationships among service quality, value, satisfaction, and future intentions of customers at an Australian sports and leisure center. Sport Management Review, 5(1), 25 - 43

NEWMAN, J.W., \& WERBEL, R.A., (1973). Multivariate analysis of brand loyalty for major household appliances. Journal of Marketing Research, 10, 404-409

OLIVER, R.L., (1993). A conceptual model of service quality and service satisfaction: compatible goals, different concepts. Advances in Service Marketing and Management, 2(4), 65-85

OLIVER, R.L., (1997). Satisfaction: A behavioural perspective on the consumer. McGraw Hill, NY

PARASURAMAN, A., ZEITHAML, V.A., BERRY, L.L., (1985). A conceptual model of service quality and its implications for future research. Journal of Marketing, 49(4), 41-50

PARASURAMAN, A., ZEITHAML, V.A., \& BERRY, L.L., (1988). SERVQUAL: A multiple-item scale for assessing consumer perceptions of service quality. Journal of Retailing, 64 (1), 12-35 


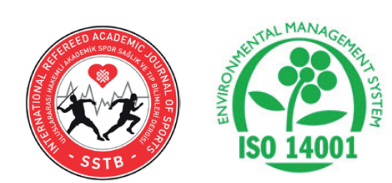

SSTB

www.sstbdergisi.com

Uluslararası Hakemli Akademik Spor Sağlık Ve Tıp Bilimleri Dergisi

Temmuz / Ağustos / Eylül - Yaz Sonbahar Dönemi Cilt: 5 Sayı: 16 Yıl:2015

International Refereed Academic Journal of Sports, Health and Medical Sciences

July / August / September - Summer Autumn Period Volume: 5 Issue: 16 Year: 2015

JEL CODE: I0-I10-I19 ID:222 K:278

ISSN Print: 2146-8508 Online 2147-1711

(ISO 9001-2008 Belge No / Document No: 12879 \& ISO 14001-2004 Belge No / Document No: 12880)

(MARKA PATENT NO: TRADEMARK)

(2015/04315- 2015-GE-18972)

RUST, R.T., \& OLIVER, R.L.L., (1993). Servicer Quality: New Directions in Theory and Practice, Sage Publications, California

SAPPEY, J., \& MACONACHIE, G., (2012). Ocular centric labor: 'You don't do this for money'. Industrial Relations, 67(3), $505-525$

SENEKHAM, T., (2008). Customers' expectations of service quality in Thai University fitness centers in Bangkok Metropolitan area, Kingdom of Thailand, Doctoral Dissertation, Faculty of the United States Sports Academy, Alabama

SMITH, J., MURRAY, D., \& HOWAT, G., (2014). How perceptions of physique can influence customer satisfaction in health and fitness centers, Managing Leisure, $19(6), 442-460$

SOITA, P.W., (2012). Measuring perceived service quality using SERVQUAL: A Case study of the Uganda health and fitness sector. International Journal of Business and Social Science, 3(5), 261-271

SOTO-ACOSTA, P., \& O-CERDAN, A.L.M., (2008). Analyzing e-business value creation from a resource-based perspective. International Journal of Information Management, 28, 49-60
TAYLOR, S., \& BAKER, T., (1994). An assessment of the relationship between service quality and customer satisfaction in the formation of consumers' purchase intentions. Journal of Retailing, (2), 70, 163-178

TIAN-COLE, S., CROMPTON, J., \& WILSON, V., (2002). An empirical investigation of the relation- ships between service quality, satisfaction and behavioral intentions among visitors to a wildlife refuge. Journal of Leisure Research, 34, 1-34

WEST, S.G., FINCH, J.E., \& CURRAN, P.J., (1995). Structural equation models with non-normal variables: problems and remedies. In Hoyle, R. H. (ed.) Structural equation modeling: Concepts, issues, and applications. Thousand Oaks, CA, US: Sage, (56-75).

WU, M., (2014). Cross-border comparative studies of service quality and consumer satisfaction: some empirical results. Eurasian Bus Rev, 4, 89-106

YU, H.S., ZHANG, J.J., KIM, D.H., \& HUANG, H., (2014). Service quality, perceived value, customer satisfaction, and behavioural intention among fitness center members aged 60 years and over. Social Behaviour and Personality, 42(5), 757-768 

JEL CODE: I0-I10-I19 ID:222 K:278

ISSN Print: 2146-8508 Online 2147-1711

(ISO 9001-2008 Belge No / Document No: 12879 \& ISO 14001-2004 Belge No / Document No: 12880) (MARKA PATENT NO: TRADEMARK)

(2015/04315- 2015-GE-18972)

ZEITHAML, V.A., PARASURAMAN, A., \& BERRY, L.L., (1990). Delivering quality service: Balancing customer perceptions and expectations. The Free Press, NY

ZEITHAML, V.A., BERRY, L.L., \& PARASURAMAN, A., (1996). The behavioral consequences of service quality. Journal of Marketing, 60,31-46
ZEITHAML, V.A., \& BITNER, M.J., (2003). Services marketing: Integrating customer focus across the firm. McGraw-Hill, New York 